Supporting information for

\title{
Helical Chirality Inversion of Poly(biphenylacetylene) with Hydroxyl Groups Induced by a Single
}

\section{Enantiomer and Memory of the Helices}

\author{
Yuanyuan Gu, ${ }^{1}$ Lijia Liu, ${ }^{1 *}$ Yudan Wang,${ }^{1 *}$ Chunhong Zhang, ${ }^{1}$ Hongxing Dong 1 \\ ${ }^{1}$ Key Laboratory of Superlight Materials and Surface Technology, Ministry of Education, College of Materials \\ Science and Chemical Engineering, Harbin Engineering University, Harbin, 150001, China.
}

E-mail:liulijia@hrbeu.edu.cn anddqllj2000@163.com

\section{S1 Experimental}

S1.1 Materials

Trimethylamine $\left(\mathrm{Et}_{3} \mathrm{~N}\right)$ was distilled and dried over $\mathrm{KOH}$ pellets under nitrogen. Dimethyl sulfoxide (DMSO) was dried over calcium hydride and distilled under reduced pressure. Tetrahydrofuran (THF) was dried over sodium and benzophenone as indicator, followed by vacuum distillation under nitrogen. 4-Bromophenoles, 1Bromododecane, $\quad$ bis(pinacolato)diboron, $\quad(98+\%), \quad 1,4-$ Dibromobenzene, $\quad\left[1,1^{\prime}-\right.$ Bis(diphenylphosphino)ferrocene]dichloropalladium(II) ( $\left.\mathrm{PdCl}_{2}(\mathrm{dppf})\right), \quad$ tetrakis(triphenylphosphine)palladium, bis(triphenylphosphine)palladium(II) dichloride were purchased from Energy Chemical (Shanghai, China), and used as received. Triphenylphosphine and $[\mathrm{Rh}(\mathrm{nbd}) \mathrm{Cl}]_{2}(\mathrm{nbd}=2,5$-norbornadiene) purchased from Aldrich Chemical Co., Inc., were used as received. 2-methyl-3-butyn-2-ol and optically active compounds were purchased from Tokyo Chemical Industry Co., Ltd. (TCI), and used without further purification. Dialysis membrane, Spectra/Pro 6 (regenerated cellulose), 3K MWCO was purchased from Spectrum Laboratories Inc. 
S1.2 Synthesis and polymerization of BPhPA
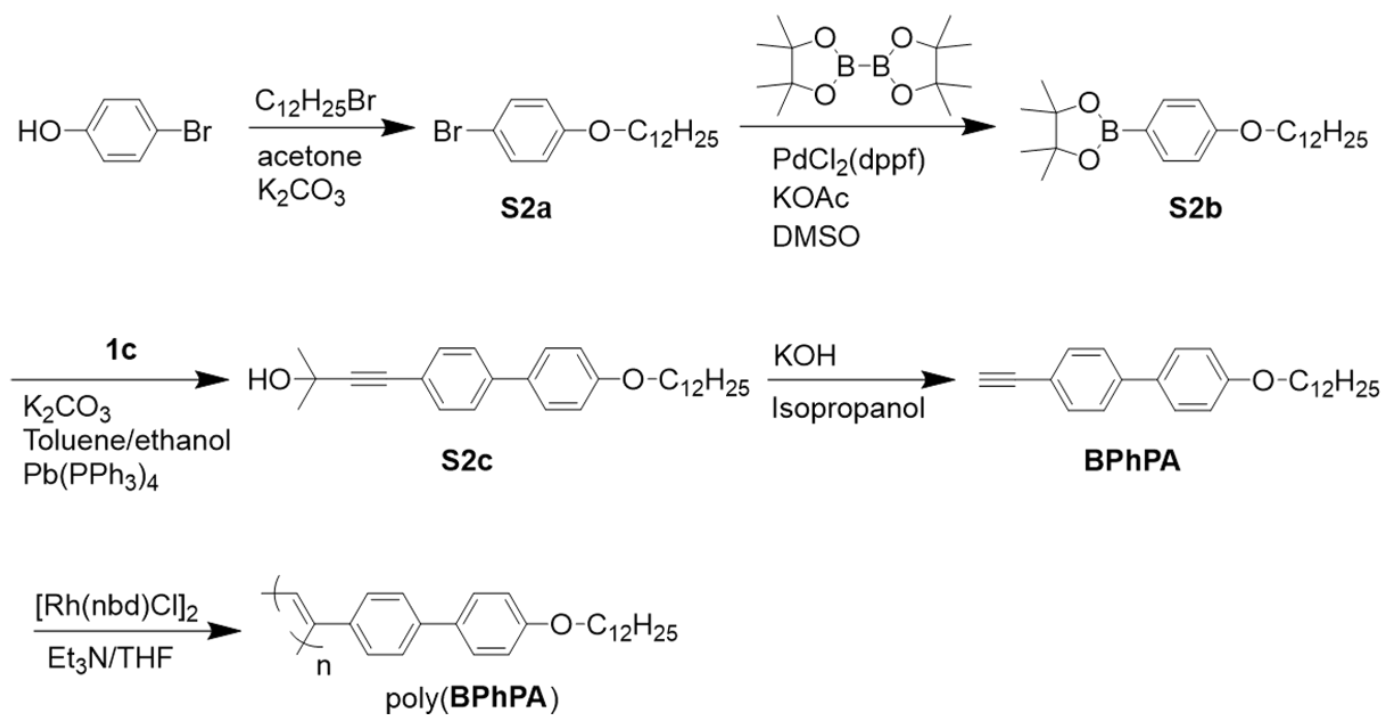

Scheme S1. Synthetic and polymerization of BPhPA

BPhPA was synthesized according to Scheme S1.

Compound S2a was prepared according to the previous work ${ }^{\mathrm{S} 1}$, S2a: Yield: $89.1 \% .{ }^{1} \mathrm{H}-\mathrm{NMR}\left(500 \mathrm{MHz}, \mathrm{CDCl}_{3}\right)$ : $\delta 7.53(\mathrm{~d}, 2 \mathrm{H}, \mathrm{Ph} H), 6.92(\mathrm{~d}, 2 \mathrm{H}, \mathrm{Ph} H), 3.97\left(\mathrm{t}, 2 \mathrm{H}, \mathrm{PhOCH}_{2}\right), 1.78\left(\mathrm{~m}, 2 \mathrm{H}, \mathrm{O}\left(\mathrm{CH}_{2}\right)\left(\mathrm{CH}_{2}\right)\left(\mathrm{CH}_{2}\right)_{9} \mathrm{CH}_{3}\right), 1.61-1.17(\mathrm{~m}$, 18H, O(CH $\left.\left(\mathrm{CH}_{2}\right)\left(\mathrm{CH}_{2}\right)\left(\mathrm{CH}_{2}\right)_{9} \mathrm{CH}_{3}\right), 0.87\left(\mathrm{t}, 3 \mathrm{H}, \mathrm{O}\left(\mathrm{CH}_{2}\right)\left(\mathrm{CH}_{2}\right)\left(\mathrm{CH}_{2}\right)_{9} \mathrm{CH}_{3}\right)$.

S2b: A mixture of S2a (2.86 g, $8.39 \mathrm{mmol})$, bis(boronate)pinacol ester (6.38 g, $25.14 \mathrm{mmol})$, KOAc $(2.69 \mathrm{~g}, 25.75$ mmol), $\mathrm{PdCl}_{2}$ (dppf) (0.25 g, $\left.0.34 \mathrm{mmol}\right)$ was dissolved in $50 \mathrm{~mL}$ distilled dimethyl sulfoxide (DMSO) under nitrogen atmosphere. The reaction mixture stirring for 24 hours at $80^{\circ} \mathrm{C}$, the reaction was terminated by addition of ice water and extracted with dichloromethane. After solvent evaporation, the crude product was purified by silica-gel column chromatography (petroleum ether/ ethyl acetate: $3 / 1 \mathrm{v} / \mathrm{v}$ ) to give $\mathbf{S 2 b}$ as a yellow solid. Yield: $55.1 \% .{ }^{1} \mathrm{H}-\mathrm{NMR}$ $\left(500 \mathrm{MHz}, \mathrm{CDCl}_{3}\right): \delta 7.23(\mathrm{~d}, 2 \mathrm{H}, \mathrm{Ph} H), 6.89(\mathrm{~d}, 2 \mathrm{H}, \mathrm{Ph} H), 3.97\left(\mathrm{t}, 2 \mathrm{H}, \mathrm{PhOCH}_{2}\right), 1.77(\mathrm{~m}, 2 \mathrm{H}$, $\left.\left.\mathrm{O}\left(\mathrm{CH}_{2}\right)\left(\mathrm{CH}_{2}\right)\left(\mathrm{CH}_{2}\right)_{9} \mathrm{CH}_{3}\right), \quad 1.48-1.20 \quad\left(\mathrm{~m}, \quad 30 \mathrm{H}, \quad \mathrm{O}\left(\mathrm{CH}_{2}\right)\left(\mathrm{CH}_{2}\right)\left(\mathrm{CH}_{2}\right)_{9} \mathrm{CH}_{3}\right), \mathrm{OC}\left(\mathrm{CH}_{3}\right)_{2}\right), \quad 0.88 \quad(\mathrm{t}, \quad 3 \mathrm{H}$, 
$\left.\mathrm{O}\left(\mathrm{CH}_{2}\right)\left(\mathrm{CH}_{2}\right)\left(\mathrm{CH}_{2}\right)_{9} \mathrm{CH}_{3}\right)$.

S2c: S2b (1.40 g, $3.62 \mathrm{mmol}), \mathbf{1 c}(0.91 \mathrm{~g}, 3.84 \mathrm{mmol})$ and $\mathrm{Pb}\left(\mathrm{PPh}_{3}\right)_{4}(0.09 \mathrm{~g}, 0.08 \mathrm{mmol})$ was dissolved in dry toluene under nitrogen atmosphere at room temperature. After addition of $20 \mathrm{~mL}$ ethanol and $45 \mathrm{~mL} \mathrm{~K}_{2} \mathrm{CO}_{3}$ aqueous solution ( $2 \mathrm{~mol} / \mathrm{L}$ ), the mixture was refluxed for 24 hours at $80^{\circ} \mathrm{C}$. The reaction was terminated by addition of ice water and extracted with dichloromethane. After solvent evaporation, the crude product was purified by silica-gel column chromatography (petroleum ether/ ethyl acetate: $3 / 1 \mathrm{v} / \mathrm{v}$ ) to give $\mathbf{S 2 c}$ as a white solid. Yield: $60.7 \% .{ }^{1} \mathrm{H}-\mathrm{NMR}$ (500MHz, $\left.\mathrm{CDCl}_{3}\right): \delta 7.51$ (d, 2H, $\left.\mathrm{Ph} H\right), 7.49(\mathrm{~s}, 4 \mathrm{H}, \mathrm{Ph} H), 6.95(\mathrm{~d}, 2 \mathrm{H}, \mathrm{Ph} H), 3.98\left(\mathrm{t}, 2 \mathrm{H}, \mathrm{PhOCH}_{2}\right), 1.55(\mathrm{~m}, 2 \mathrm{H}$, $\left.\mathrm{O}\left(\mathrm{CH}_{2}\right)\left(\mathrm{CH}_{2}\right)\left(\mathrm{CH}_{2}\right)_{9} \mathrm{CH}_{3}\right), 1.61\left(\mathrm{~s}, 6 \mathrm{H}, \mathrm{C}\left(\mathrm{CH}_{3}\right)_{2} \mathrm{OH}\right), 1.48-1.21\left(\mathrm{~m}, 18 \mathrm{H} \mathrm{O}\left(\mathrm{CH}_{2}\right)\left(\mathrm{CH}_{2}\right)\left(\mathrm{CH}_{2}\right)_{9} \mathrm{CH}_{3}\right), 0.88(\mathrm{t}, 3 \mathrm{H}$, $\left.\mathrm{O}\left(\mathrm{CH}_{2}\right)\left(\mathrm{CH}_{2}\right)\left(\mathrm{CH}_{2}\right)_{9} \mathrm{CH}_{3}\right)$.

BPhPA: A mixture of S2c $(0.52 \mathrm{~g}, 1.22 \mathrm{mmol}), \mathrm{KOH}(0.41 \mathrm{~g}, 7.35 \mathrm{mmol})$ was dissolved in $50 \mathrm{~mL}$ isopropanol at $80{ }^{\circ} \mathrm{C}$. The reaction solution was adjusted to neutrality with $1 \mathrm{~mol} / \mathrm{L} \mathrm{HCl}$ aqueous solution, then extracted by dichloromethane. The crude product was purified by silica-gel column chromatography (petroleum ether/ ethyl acetate: $2 / 1 \mathrm{v} / \mathrm{v})$ to give $\mathbf{B P h P A}$ as a yellow solid. Yield: $78.9 \% .{ }^{1} \mathrm{H}-\mathrm{NMR}\left(500 \mathrm{MHz}, \mathrm{CDCl}_{3}\right): \delta 7.66-7.63(\mathrm{~m}, 6 \mathrm{H}$, $\mathrm{Ph} H), 6.96(\mathrm{~d}, 2 \mathrm{H}, \mathrm{Ph} H), 3.99$ (t, 2H, $\left.\mathrm{PhOCH}_{2}\right), 3.12$ (s, $\left.1 \mathrm{H} \mathrm{CCH}\right), 1.55\left(\mathrm{~m}, 2 \mathrm{H}, \mathrm{O}\left(\mathrm{CH}_{2}\right)\left(\mathrm{CH}_{2}\right)\left(\mathrm{CH}_{2}\right)_{9} \mathrm{CH}_{3}\right), 1.50-$ $1.18\left(\mathrm{~m}, 18 \mathrm{H} \mathrm{O}\left(\mathrm{CH}_{2}\right)\left(\mathrm{CH}_{2}\right)\left(\mathrm{CH}_{2}\right)_{9} \mathrm{CH}_{3}\right), 0.89\left(\mathrm{t}, 3 \mathrm{H}, \mathrm{O}\left(\mathrm{CH}_{2}\right)\left(\mathrm{CH}_{2}\right)\left(\mathrm{CH}_{2}\right)_{9} \mathrm{CH}_{3}\right) \cdot{ }^{13} \mathrm{C}-\mathrm{NMR}\left(101 \mathrm{MHz}, \mathrm{CDCl}_{3}\right): \delta$ $159.22,141.54,132.90,128.32,126.78,120.70,114.94,84.02,68.65,32.01,29.76-29.25,26.13,22.74,14.15$. FTIR (KBr, $\left.\mathrm{cm}^{-1}\right): 826,1251,1492,1602,2156,2853,2917,3288$. Anal. Calcd for $\mathrm{C}_{26} \mathrm{H}_{34} \mathrm{O}$ : C 86.13, H 9.45; Found: C 86.20, H 9.39.

Poly(BPhPA): Polymerization of the BPhPA was carried out as follows: under nitrogen atmosphere, a solution of $[\mathrm{Rh}(\mathrm{nbd}) \mathrm{Cl}]_{2}(0.25 \mathrm{mg}, 0.53 \mathrm{umol})$ and trimethylamine (TEA) $(18.13 \mathrm{uL}, 0.11 \mathrm{mmol})$ in $6.0 \mathrm{~mL}$ THF was added to a $2.0 \mathrm{~mL}$ THF solution of BPhPA $(96.15 \mathrm{mg}, 0.27 \mathrm{mmol})$. The reaction was stirred for 10 hours at room 
temperature and then diluted by THF, the mixture was dripped slowly into $50 \mathrm{~mL}$ methanol to isolate a red solid polymer with yield of $86.4 \% .{ }^{1} \mathrm{H}-\mathrm{NMR}\left(500 \mathrm{MHz}, \mathrm{CDCl}_{3}\right): \delta 1.91-1.10\left(20 \mathrm{H}, \mathrm{O}\left(\mathrm{CH}_{2}\right)\left(\mathrm{CH}_{2}\right)_{10} \mathrm{CH}_{3}\right), 0.92(3 \mathrm{H}$, $\left.\mathrm{O}\left(\mathrm{CH}_{2}\right)\left(\mathrm{CH}_{2}\right)\left(\mathrm{CH}_{2}\right)_{9} \mathrm{CH}_{3}\right)$. FT-IR $\left(\mathrm{KBr}, \mathrm{cm}^{-1}\right): 819,1245,1494,1607,2850,2923$, 3434. Anal. Calcd for $\mathrm{C}_{26} \mathrm{H}_{34} \mathrm{O}: \mathrm{C}$ 86.02, H 9.51; Found: C 86.11, H 9.55. Mw: 2.15x105; $M w / M n: 1.31$. And the Raman spectrum of poly(BPhPA) was shown in Figure S26. The peak at 1600 and $1537 \mathrm{~cm}^{-1}$ was assigned to the $\mathrm{cis} \mathrm{C}=\mathrm{C}$ bonds in the polymer main chain. The peak at $1337 \mathrm{~cm}^{-1}$ was assigned to the $\mathrm{C}-\mathrm{C}$ bond, coupled with the $\mathrm{C}-\mathrm{H}$ bond in the cis-polymer, which is characteristic of aromatic polyacetylene having the cis-form.

\section{S1.3 Memory of the induced helices}

$1.0 \mathrm{~mL}$ of poly $($ BPhDHPA $)$ solution $(1.0 \mathrm{mmol} / \mathrm{L})$ in solvent $/ L$-menthol $(7 / 3 \mathrm{v} / \mathrm{v}$, solvent: THF or toluene) was set in a dialysis bag (made of a regenerated cellulose membrane, Spectra/Pro 6, molecular weight cut off: $3 \mathrm{KD}$, from Spectrum Laboratories Inc.) was sunk in a beaker containing $50 \mathrm{~mL}$ mixture of solvent/phenylmethanol (7/3 v/v, solvent: THF or toluene) and a stirring bar. The mixture of solvent/phenylmethanol was renewed every $6 \mathrm{~h}, L$-menthol in the dialysis bag was replaced with achiral phenylmethanol by concentration-driven permeation through the dialysis membrane after dialysis for $48 \mathrm{~h}$.

\section{S1.4 Measurements.}

${ }^{1} \mathrm{H}$ - and ${ }^{13} \mathrm{C}-\mathrm{NMR}$ spectra were recorded on a Bruker AV 500 spectrometer. IR spectra were recorded with a JASCO FTIR 4200 spectrometer (in $\mathrm{KBr}$ tablet). The average molecular weights ( $M n$ and $M w$ ) were evaluated by gel permeation chromatography (GPC) by using JASCO liquid chromatography instruments with PU-2080, DG-208053, CO-2060, UV-2070, CD-2095, and two polystyrene gel columns (Shodex KF-807 L, THF eluent, polystyrene calibration). A certain volume of liquid chiral additive was mixed with organic solvent to produce a solution. The solid menthol was heated to $45^{\circ} \mathrm{C}$ to melt it into a liquid, then take a certain volume of menthol and dissolve it in an 
organic solvent. Poly(BPhDHPA) was solved in the solution of chiral additive/organic solvent mixture with a certain concentration. Then, circular dichroism (CD) spectra of the solution were recorded in a Jasco-815 spectropolarimeter, with a Peltier controller for temperatures, (a quartz cell of $1 \mathrm{~mm}$ path length, sample concentration: $1.0 \mathrm{mmol} / \mathrm{L}$, heating and cooling rates: 10 or $5{ }^{\circ} \mathrm{C} / \mathrm{min}$ ) $\mathrm{CD}$ absorption was measured with a sealed sample cell, when the temperature reached the setting temperature, the instrument would automatically test the sample immediately. (The volatilization of solvent is very little and can be ignored in this test). UV-vis absorption spectra were recorded on MAPADA UV-6100 double beam spectrophotometer (Shanghai, China). High performance liquid chromatograph (HPLC) analysis was conducted on JASCO PU-2089 system (Tokyo, Japan) equipped with RI detector (JASCO-RI2031), intelligent sampler (JASCO AS-2055), and chiral PAK AD-H (0.46cm x 25cm), hexane/2-propanol (90/10, $\mathrm{v} / \mathrm{v}$ ) as eluent at a flow rate of $1.0 \mathrm{~mL} \mathrm{~min}^{-1}$. The enantiomeric excess (ee) of menthol was determined as follow: optical rotation of the menthol solution was detected by a polarimeter at room temperature. Then, enantiomeric excess (ee) is defined as $\left(\alpha_{1} / \alpha_{2}\right) \times 100 \% ; \alpha_{1}$ is the optical rotation of the $L$ - and $D$-menthol mixture solution, while $\alpha_{2}$ is the optical rotation of enantiopure $L$-menthol solution at the same concentration. ${ }^{\mathrm{S} 2}$ 


\section{S2. Results and discussion}
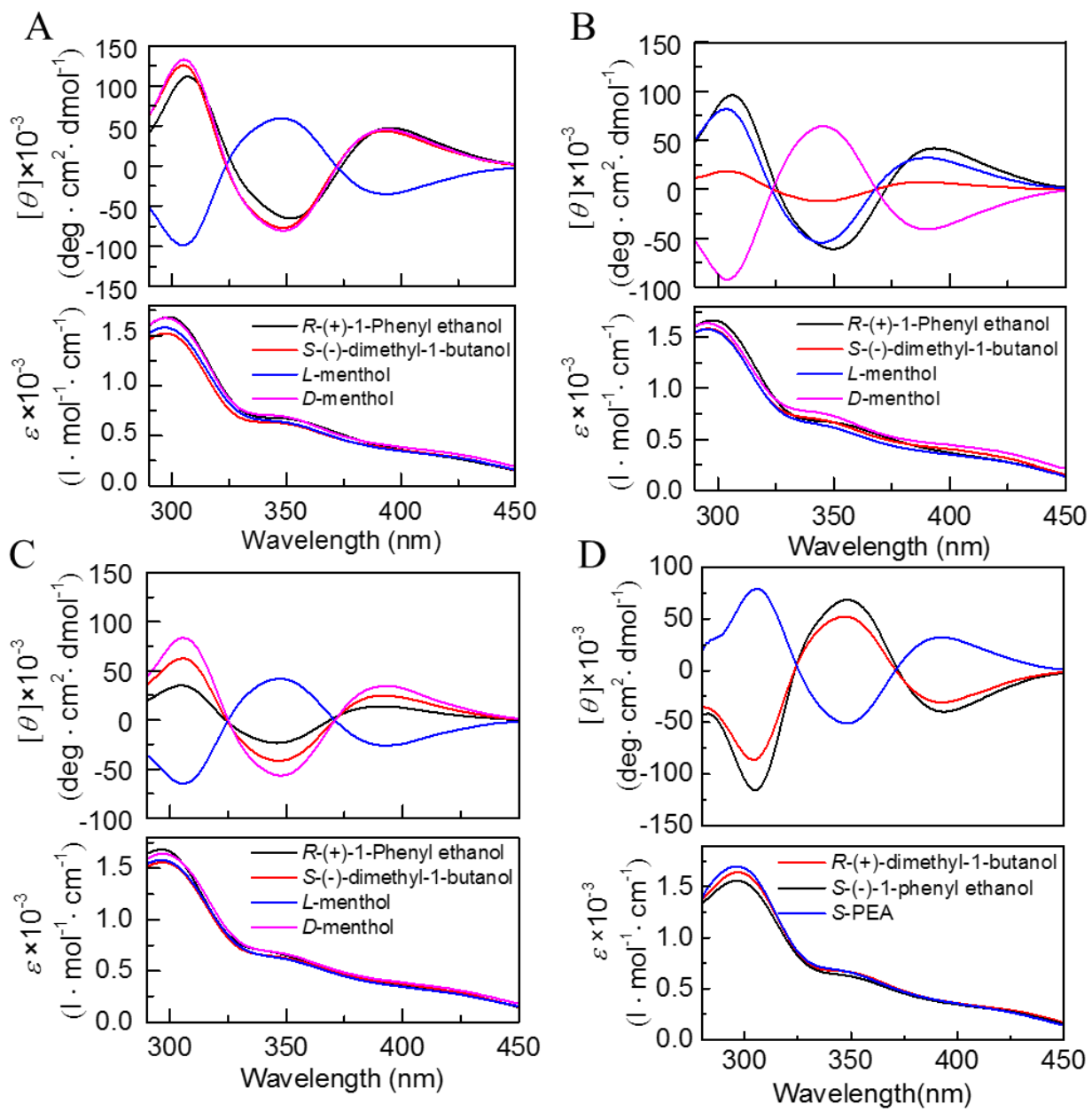

Figure S1. CD and absorption spectra of poly(BPhDHPA) induced by chiral bias $(R-(+)-1-$ phenyl ethanol (black line), $S$-(-)-dimethyl-1-butanol (red line), $L$-menthol (blue line) and $D$-menthol (magenta line)) in chloroform (A), THF (B) and tetrachloromethane (C), and CD and absorption spectra of poly(BPhDHPA)/chiral bias $(R-(+)-$ dimethyl-1-butanol, $S$-(-)-1-phenyl ethanol, and $S$-PEA) in toluene (D). ([poly (BPhDHPA) $]=1.0 \mathrm{mmol} / \mathrm{L}$, chiral bias content $=30$ vol. $\%$, temperature $=25^{\circ} \mathrm{C}$ ) 


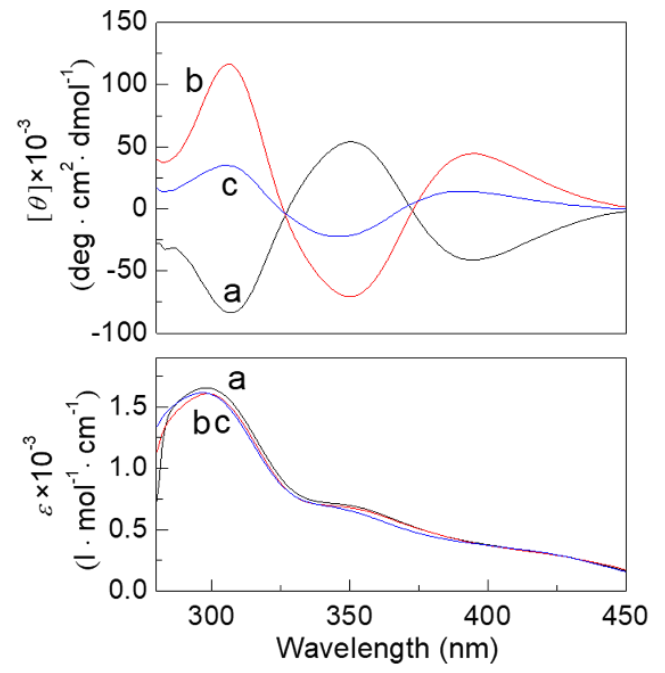

Figure S2. CD and UV spectra of poly(BPhDHPA)/R-PEA in toluene(a), $\mathrm{CHCl}_{3}(\mathrm{~b})$ and $\mathrm{THF}(\mathrm{c})$ at $25{ }^{\circ} \mathrm{C}$. $([$ poly $($ BPhDHPA $)]=1.0 \mathrm{mmol} / \mathrm{L}, R-\mathrm{PEA}$ content $=30 \mathrm{vol} . \%)$

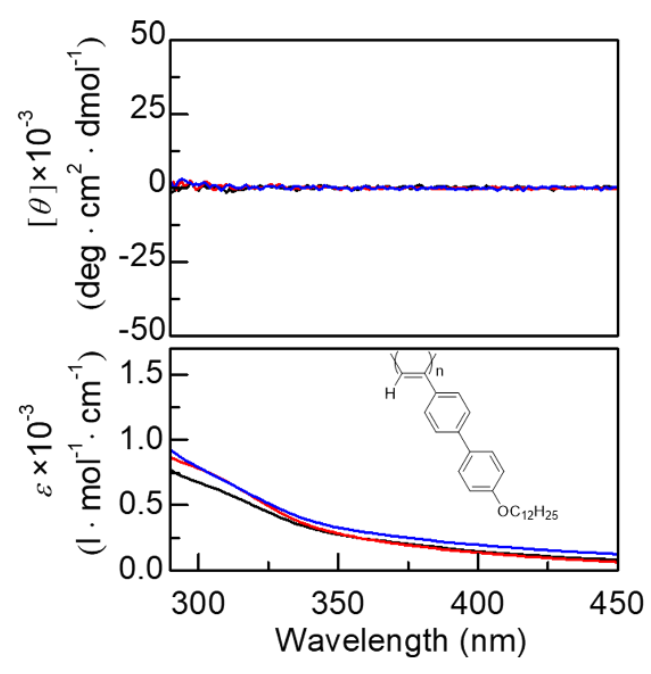

Figure S3. CD and absorption spectra of poly(BPhPA) in the presence of $L$-menthol in toluene (black line), chloroform (red line), THF (blue line) at $25{ }^{\circ} \mathrm{C} . \quad([\operatorname{poly}($ BPhPA $)]=1.0 \mathrm{mmol} / \mathrm{L}, L$-menthol content $=30 \mathrm{vol} . \%)$ 


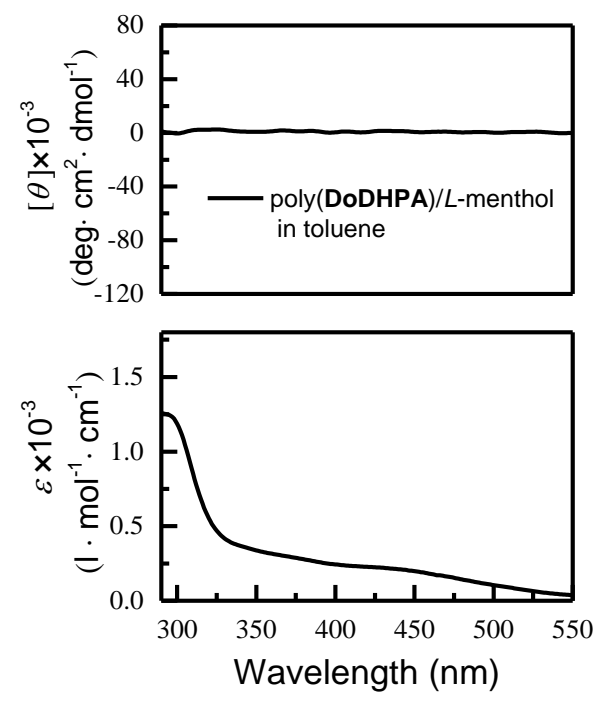

Figure S4. CD and UV-vis spectra of poly(DoDHPA $) / L$-menthol in toluene. ([polymer $]=1.0 \mathrm{mmol} / \mathrm{L}$, temperature $=25^{\circ} \mathrm{C} ; L$-menthol $/$ toluene $\left.=3 / 7 \mathrm{v} / \mathrm{v}\right)$.

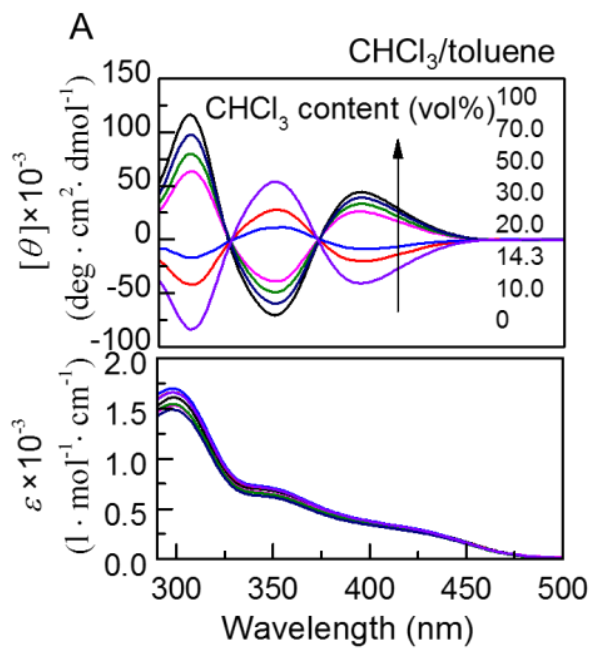

B

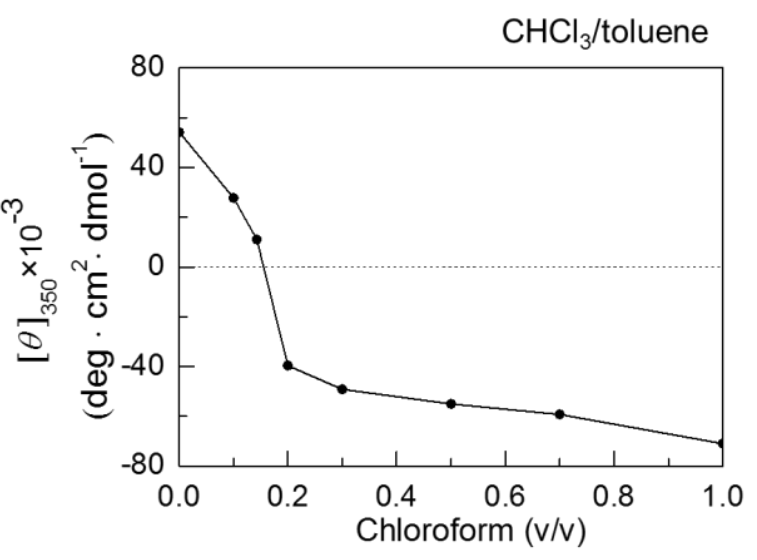

Figure S5. (A) CD and absorption spectra of poly(BPhDHPA)/R-PEA in chloroform/toluene at $25{ }^{\circ} \mathrm{C}$. (B) Plots of $[\theta]_{350}$ value versus the chloroform content in the poly $($ BPhDHPA $) / R$-PEA solution. $([\operatorname{poly}(\mathbf{B P h D H P A})]=1.0$ $\mathrm{mmol} / \mathrm{L}$; chiral additives content $=30$ vol. $\%$ ). 


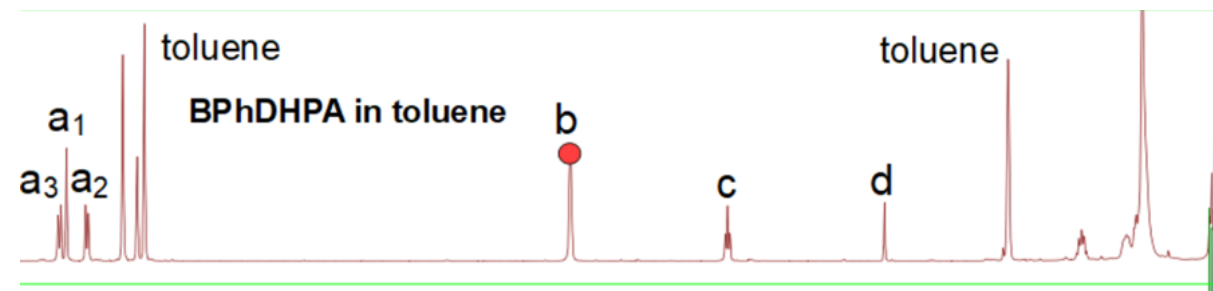

BPhDHPA/L-menthol in toluene

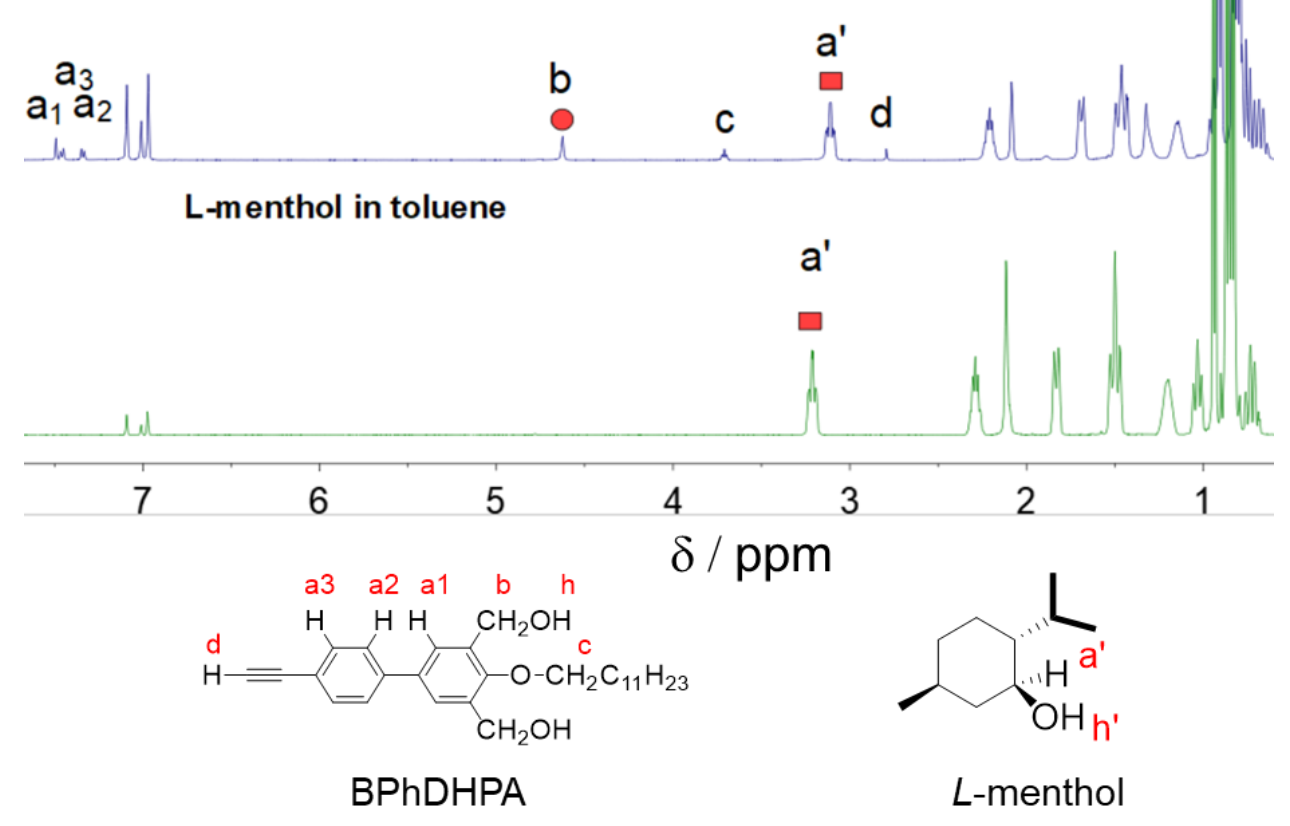

Figure S6. ${ }^{1} \mathrm{H}$-NMR spectra of the monomer BPhDHPA, $L$-menthol and BPhDHPA/ $L$-menthol complex in toluene$d 8$ at $25^{\circ} \mathrm{C}$. 


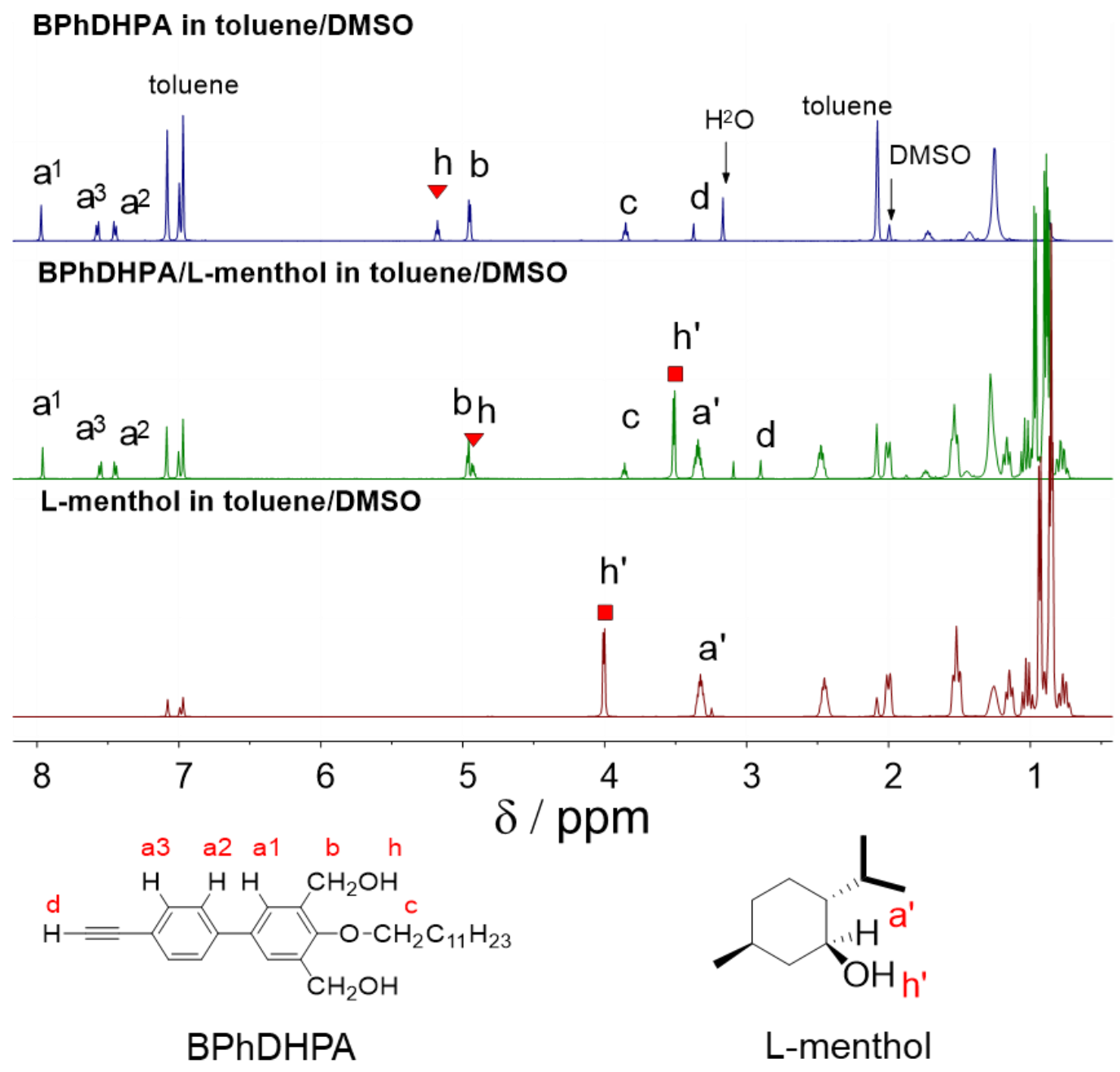

Figure S7. ${ }^{1}$ H-NMR spectra of the monomer BPhDHPA, $L$-menthol and BPhDHPA/ $L$-menthol complex in toluene$d_{8} / \mathrm{DMSO}-d_{6}$ mixture at $25{ }^{\circ} \mathrm{C}$. (toluene- $d_{8} / \mathrm{DMSO}-d_{6} \approx 4 / 1 \mathrm{v} / \mathrm{v}$ ) 


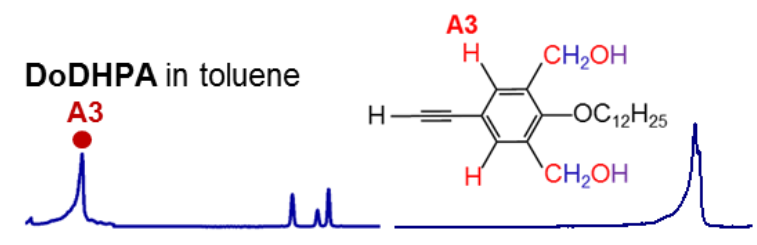

DoDHPA/L-menthol

in toluene

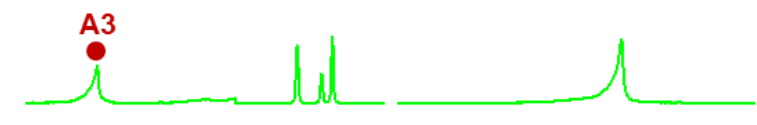

DoDHPA/L-menthol

in toluene/DMSO

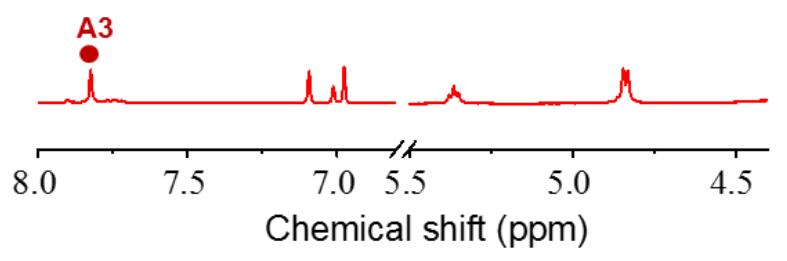

Figure S8. ${ }^{1} \mathrm{H}-\mathrm{NMR}$ spectra of the monomer DoDHPA in toluene- $d_{8}$, the complex of the monomer DoDHPA and $L$ menthol in toluene- $d_{8}$ and toluene- $d_{8} / \mathrm{DMSO}-d_{6}$ at $25^{\circ} \mathrm{C}$. (toluene- $d_{8} / \mathrm{DMSO}-d_{6} \approx 4 / 1 \mathrm{v} / \mathrm{v}$ in the mixture).

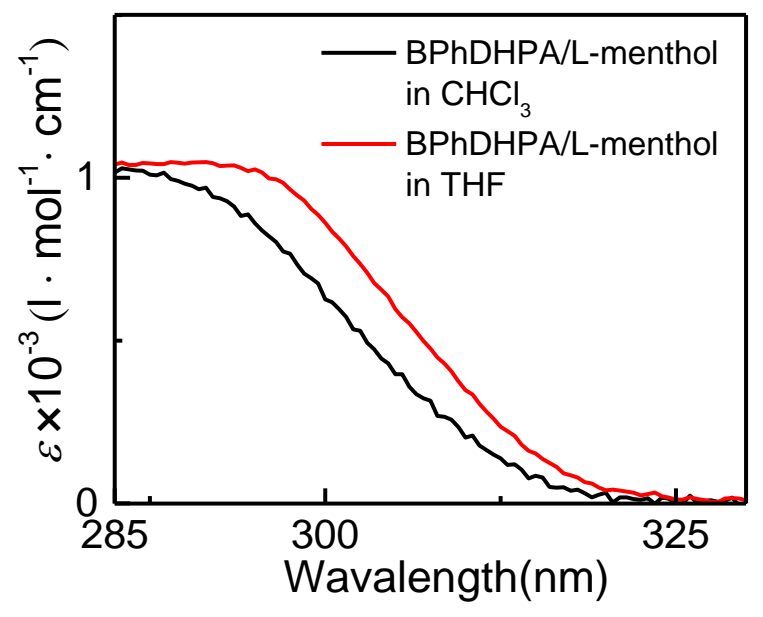

Figure S9. The absorption spectra of BPhDHPA/L-menthol in $\mathrm{CHCl}_{3}$ (black line) and THF (red line) at $25{ }^{\circ} \mathrm{C},(L$ menthol content $=30 \mathrm{vol} . \%,[$ BPhDHPA $]=1.0 \mathrm{mmol} / \mathrm{L})$ 


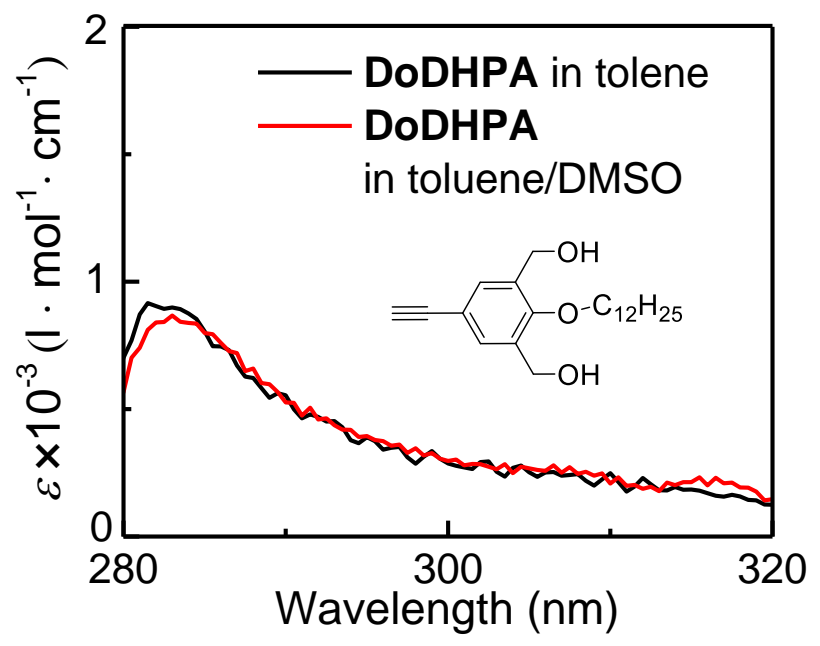

Figure S10. The absorption spectra of DoDHPA/L-menthol complex in toluene (black line) and toluene/DMSO (red line) at $25^{\circ} \mathrm{C}$, (toluene- $d_{8} / \mathrm{DMSO}-d_{6} \approx 4 / 1 \mathrm{v} / \mathrm{v}$ in the mixture)

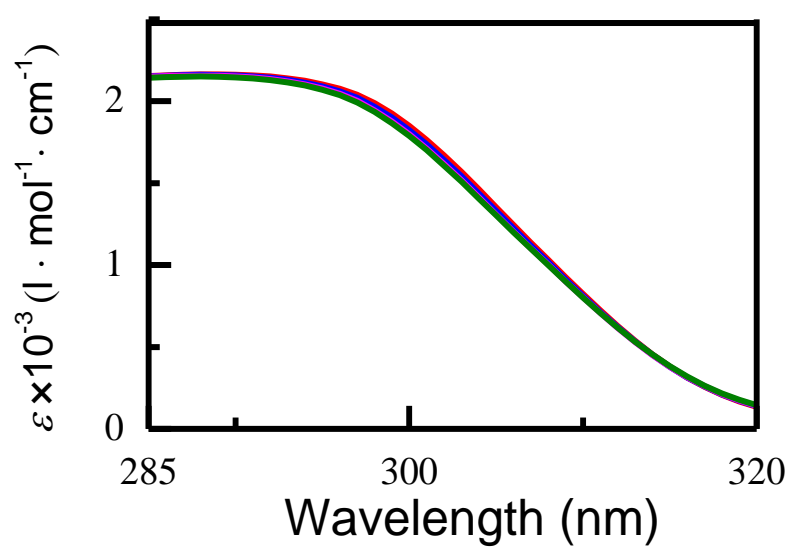

Figure S11. The absorption of the monomer BPhDHPA in THF/toluene at $-10,30$ and $60^{\circ} \mathrm{C}$, respectively. (volume ratio of toluene/THF $=1 / 9)$. 
A

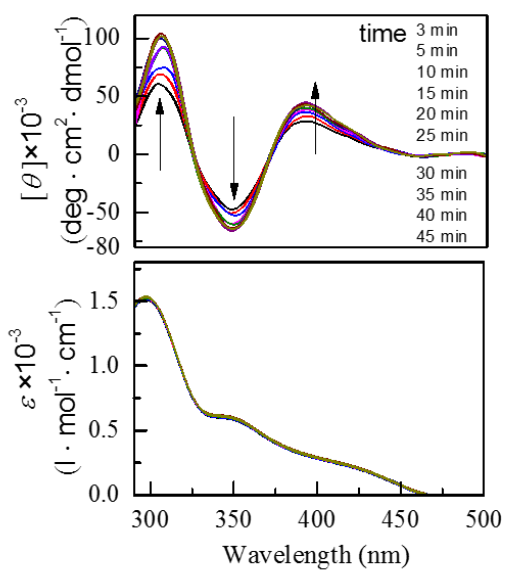

B

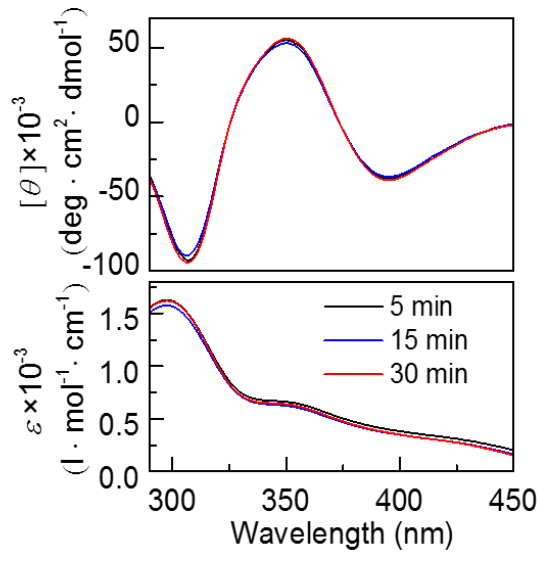

C

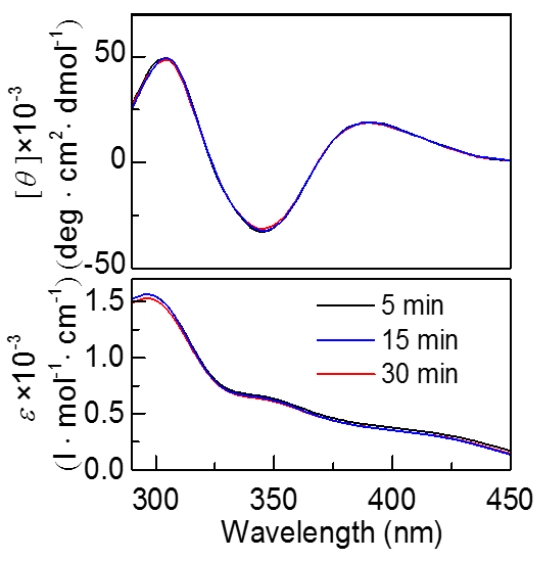

Figure S12. Time-dependent CD and UV spectral changes of poly(BPhDHPA) with $L$-menthol after standing of the sample at $-10{ }^{\circ} \mathrm{C}$ in THF/toluene (A), toluene (B), and THF (C). $\quad([\operatorname{poly}($ BPhDHPA $)]=1.0 \mathrm{mmol} / \mathrm{L}$; chiral additives content $=30 \mathrm{vol} . \%$; volume ratio of $L$-menthol/ toluene $/ \mathrm{THF}=3.0 / 0.7 / 6.3$ for A).
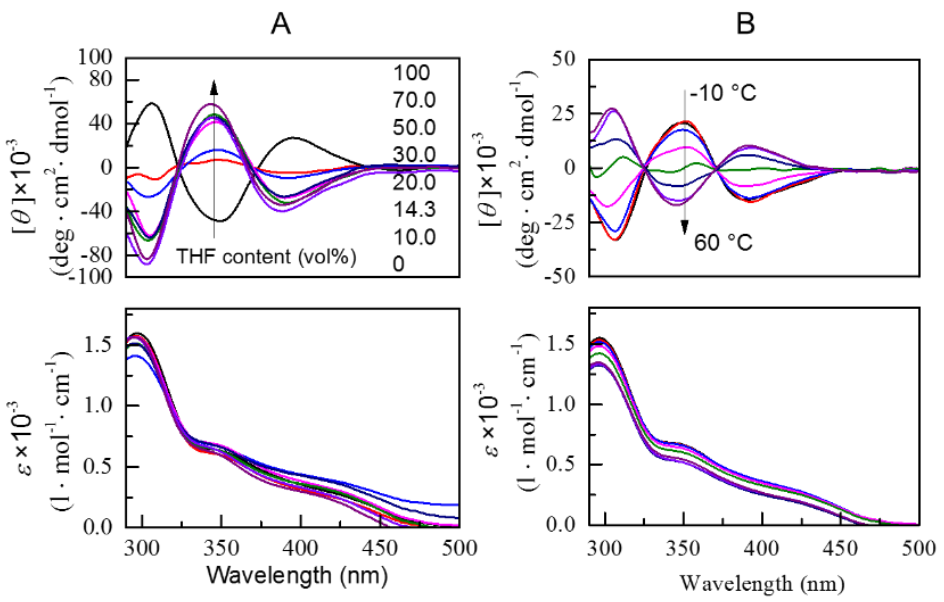

Figure S13. (A) CD and UV spectra of poly(BPhDHPA)/D-menthol complex in THF/toluene with different THF content at $25^{\circ} \mathrm{C}$. (B) CD and UV spectra of poly(BPhDHPA) induced by $D$-menthol in THF/toluene at the temperature from $-10{ }^{\circ} \mathrm{C}$ to $60{ }^{\circ} \mathrm{C} .([$ poly $($ BPhDHPA $)]=1.0 \mathrm{mmol} / \mathrm{L}$; chiral additives content $=30 \mathrm{vol} . \%$; volume ratio of $D$-menthol $/$ toluene $/ \mathrm{THF}=3.0 / 0.7 / 6.3$ for $\mathrm{B}$ ). 


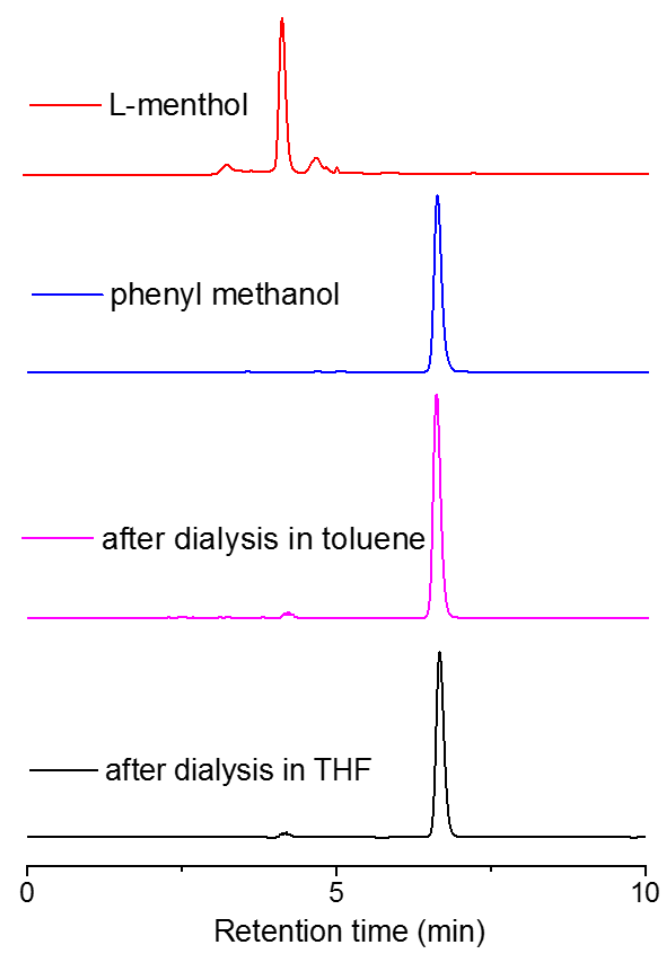

Figure S14. HPLC curves of $L$-menthol (red line), phenylmethanol (blue line), and the solution in dialysis bag after dialysis in toluene (magenta line) and THF (black line) with hexane/2-propanol (90/10, v/v) as eluent.

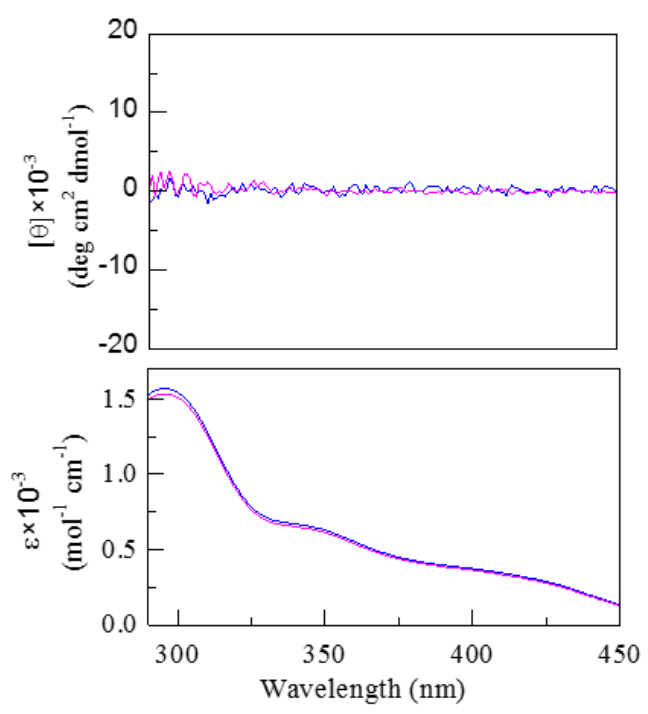

Figure S15. CD and UV spectra of the $\operatorname{poly}($ BPhDHPA $) / L$-menthol in phenylmethanol/THF (blue line) and phenylmethanol/toluene (red) at $25^{\circ} \mathrm{C}$ at a low $/ L$-menthol content. $([$ poly $($ BPhDHPA $)]=1.0 \mathrm{mmol} / \mathrm{L},(L-\mathrm{menthol}$ + phenylmethanol $) / \operatorname{THF}($ or toluene $)=3 / 7 \mathrm{v} / \mathrm{v}, L$-menthol $/($ phenylmethanol $+\operatorname{THF}($ or toluene $))=0.005 / 1 \mathrm{v} / \mathrm{v})$. 
A
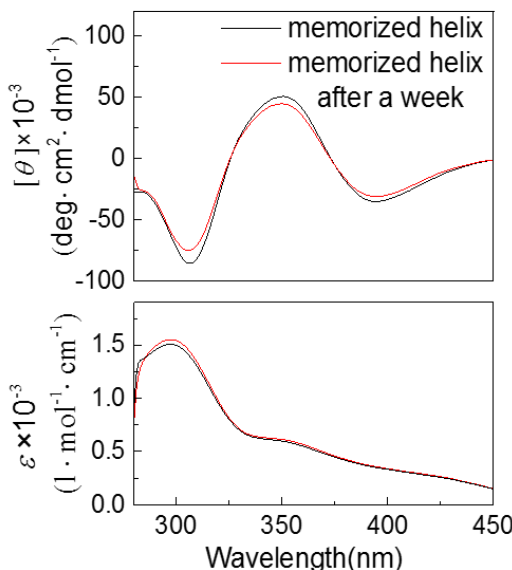

B THF
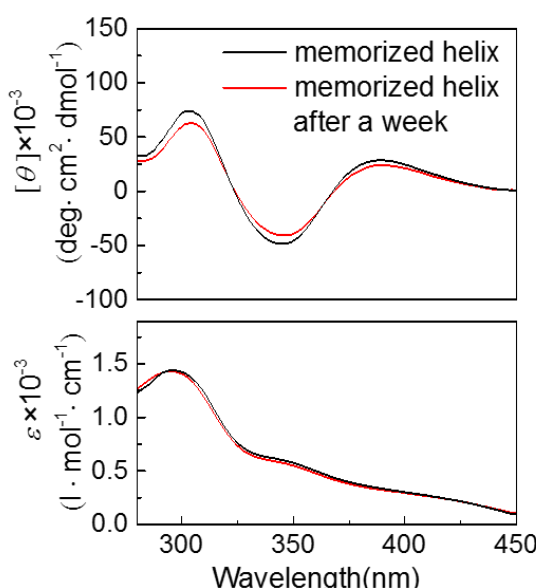

Figure S16. CD and UV-vis spectra of memorized helix (black line) of the poly(BPhDHPA) after replacing $L$-menthol with achiral phenylmethanol and the memorized helix after a week (red line) in toluene (A) and THF

$([$ poly $($ BPhDHPA $)]=1.0 \mathrm{mmol} / \mathrm{L})$.
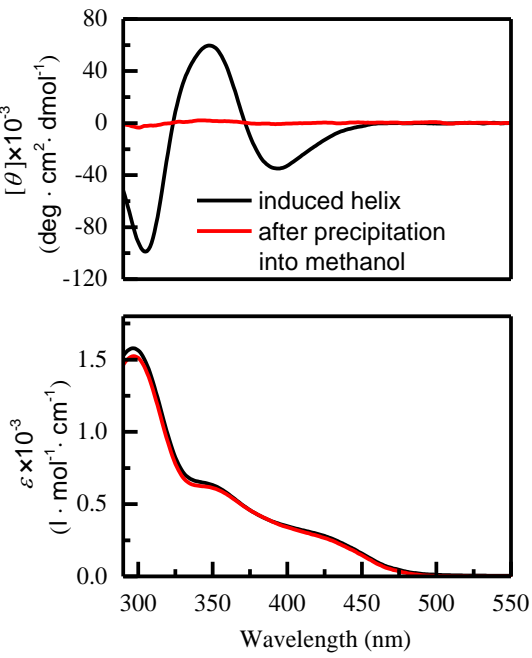

Figure S17. CD and UV-vis spectra of poly $($ BPhDHPA $) / L$-menthol in toluene $(L$-menthol/toluene $=3 / 7 \mathrm{v} / \mathrm{v}$ (black line)); and the toluene solution of the isolated poly(BPhDHPA) after precipitation in methanol (red line). ([polymer] $=1.0 \mathrm{mmol} / \mathrm{L}$, temperature $\left.=25^{\circ} \mathrm{C}\right)$. 

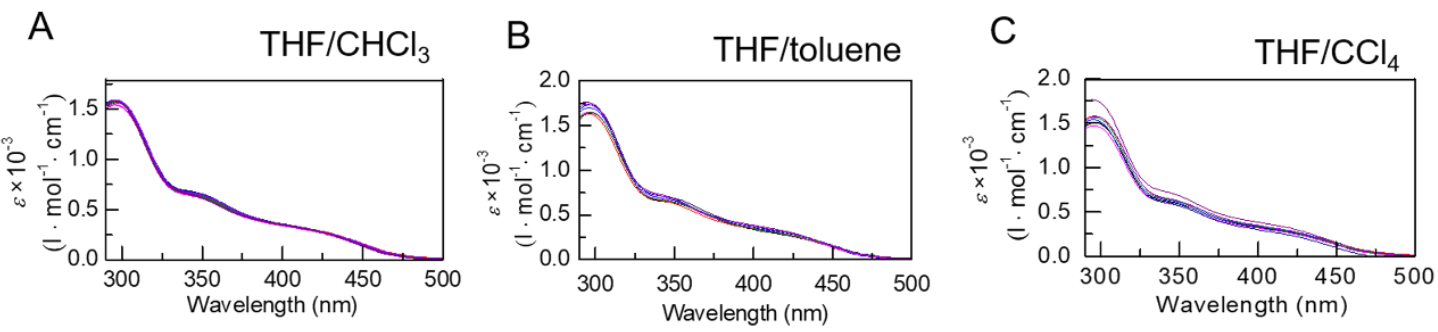

Figure S18. The absorption spectra of poly(BPhDHPA) with $L$-menthol in $\mathrm{THF} / \mathrm{CHCl}_{3}$ (A), THF/toluene (B),

$\mathrm{THF} / \mathrm{CCl}_{4}(\mathrm{C})$ at $25^{\circ} \mathrm{C} .(L$-menthol content $=30 \mathrm{vol} . \%$, $[\mathrm{poly}(\mathbf{B P h D H P A})]=1.0 \mathrm{mmol} / \mathrm{L})$

\section{S3. Characterization of the monomers and polymers}

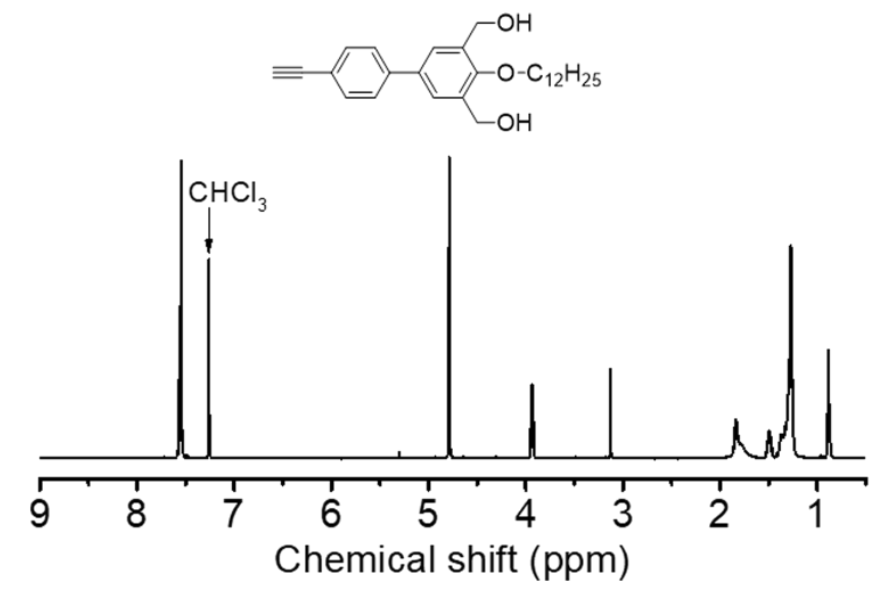

Figure S19. ${ }^{1} \mathrm{H}-\mathrm{NMR}$ spectrum of BPhDHPA. (in $\mathrm{CDCl}_{3}$ ) 


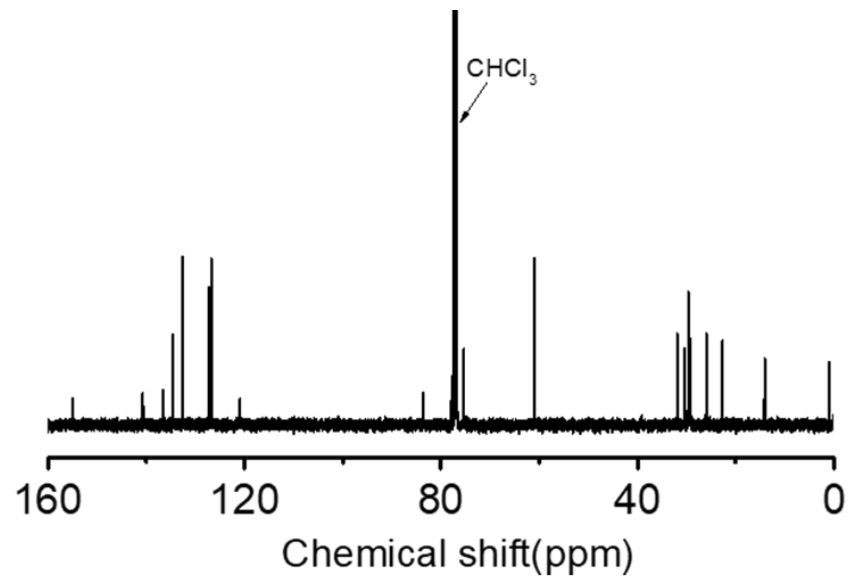

Figure S20. ${ }^{13}$ C-NMR spectrum of BPhDHPA. (in $\mathrm{CDCl}_{3}$ )

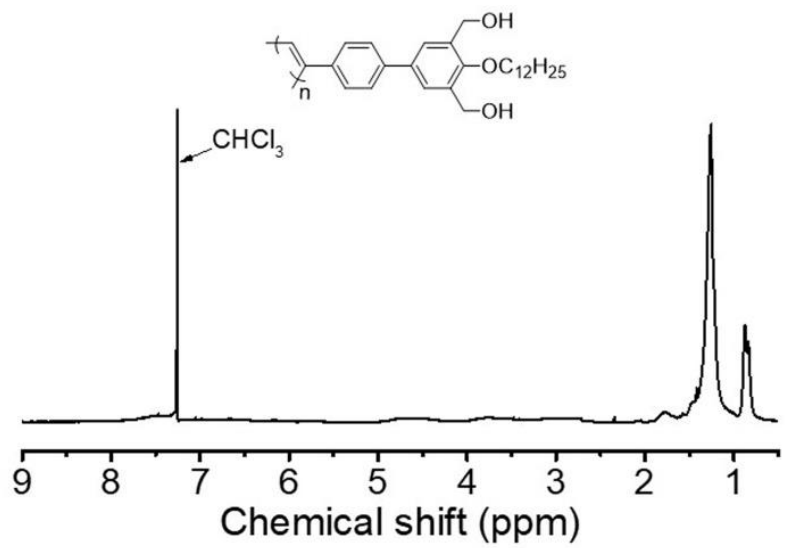

Figure S21. ${ }^{1} \mathrm{H}-\mathrm{NMR}$ spectrum of poly(BPhDHPA). (in $\mathrm{CDCl}_{3}$ ) 


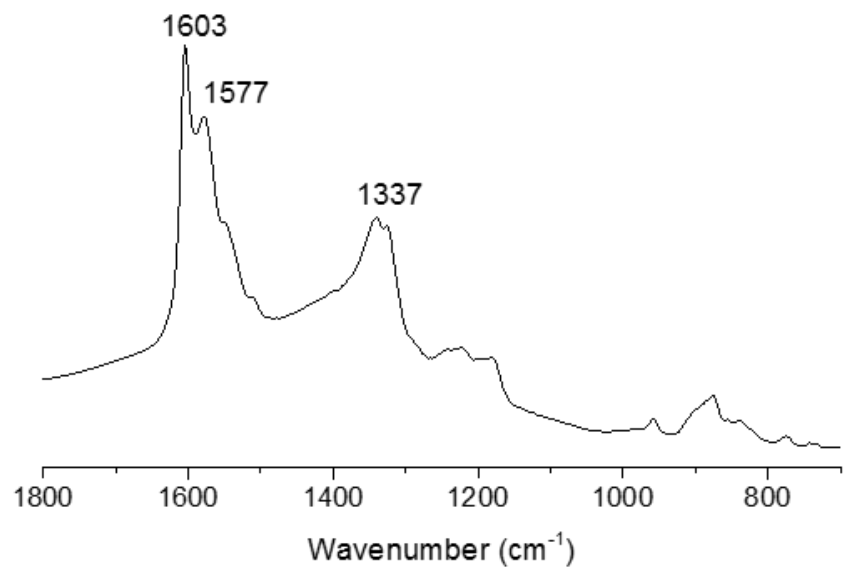

Figure S22. Raman spectrum of poly(BPhDHPA) in solid state. Spectrum were collected at ambient temperature: $\lambda$ excit $=638 \mathrm{~nm}$.

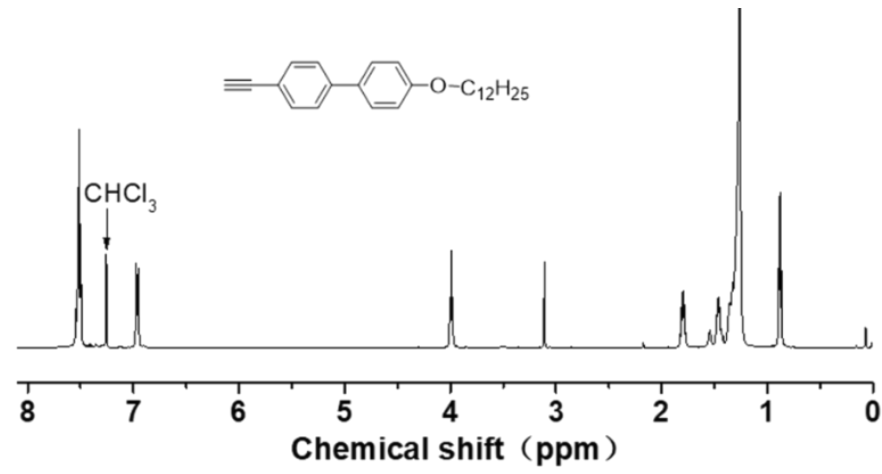

Figure S23. ${ }^{1} \mathrm{H}-\mathrm{NMR}$ spectrum of BPhPA. (in $\mathrm{CDCl}_{3}$ ) 

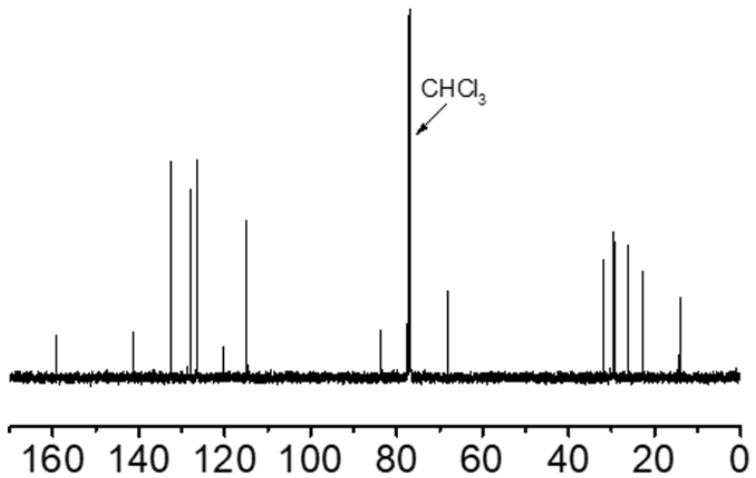

Chemical shift (ppm)

Figure S24. ${ }^{13} \mathrm{C}-\mathrm{NMR}$ spectrum of BPhPA. (in $\mathrm{CDCl}_{3}$ )

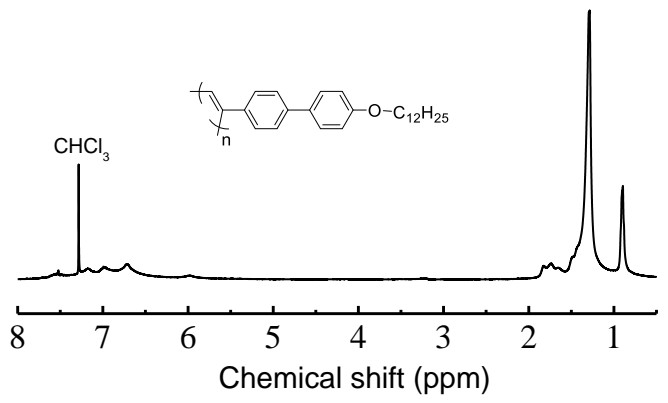

Figure S25. ${ }^{1} \mathrm{H}-\mathrm{NMR}$ spectrum of poly(BPhPA). (in $\left.\mathrm{CDCl}_{3}\right)$

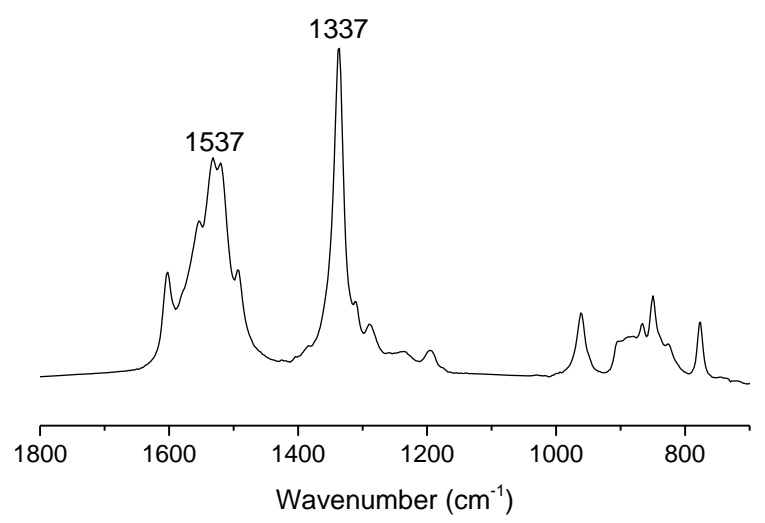

Figure S26. Raman spectrum of poly(BPhPA) in solid state. Spectrum were collected at ambient temperature: $\lambda$ excit $=638 \mathrm{~nm}$. 


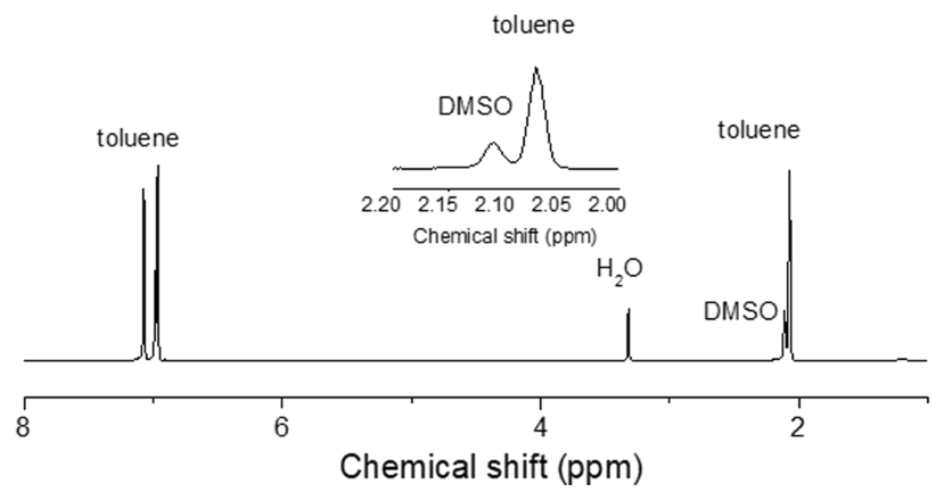

Figure S27. ${ }^{1} \mathrm{H}$ NMR spectrum of toluene- $d_{8} / \mathrm{DMSO}-d_{6}(8 / 2, \mathrm{v} / \mathrm{v})$ mixture.

\section{References}

(S1) Liu, L. J.; Zang, Y.; Hadano, S.; Aoki, T.; Teraguchi, M.; Kaneko, T.; Namikoshi, T. New Achiral Phenylacetylene Monomers Having an Oligosiloxanyl Group Most Suitable for Helix-Sense-Selective Polymerization and for Obtaining Good Optical Resolution Membrane Materials. Macromolecules 2010, 43, 9268-9276. DOI: 10.1021/ma101999k

(S2) Liang, J. Y.; Deng, J. P. A Chiral Interpenetrating Polymer Network Constructed by Helical Substituted Polyacetylenes and Used for Glucose Adsorption. Polym Chem, 2013, 8, 1426-1434. DOI: 10.1039/c7py00025a 